\title{
The IRX3 Gene; the Missing Link between the FTO Gene and Obesity
}

\author{
Saeid Doaei ${ }^{1}$, Maryam Gholamalizadeh ${ }^{2}$, Alireza Mosavi Jarrahi ${ }^{3}$, Marjan \\ Badakhanian $^{4}$, Rahim Najafi ${ }^{5}$
}

${ }^{1}$ Students 'Research Committee, National Nutrition and Food Technology Research Institute, Faculty of Nutrition Sciences and Food Technology, Shahid Beheshti University of Medical Sciences, Tehran, Iran. ${ }^{2}$ Students 'Research Committee, Cancer Research Center, Shahid Beheshti University of Medical Sciences, Tehran, Iran. ${ }^{3}$ Faculty of Medical School, Shahid Beheshti University of Medical Sciences, Tehran, Iran. ${ }^{4}$ Food Security Research Center and Department of Clinical Nutrition, School of Nutrition and Food Science, Isfahan University of Medical Sciences, Isfahan, Iran. ${ }^{5}$ Urmia University of Medical Sciences, Urmia, Iran.

\begin{abstract}
Aims: The aim of this study was the investigation of the mediator role of the IRX3 gene in the relationship between the FTO gene and obesity. Materials and Methods: All related articles published in English from June 1990 to February 2017 were studied. Results: Only a Few studies have examined the association between the IRX3 gene with the FTO gene and obesity. However, all of them reported that the FTO gene can influence the IRX3 gene expression. Also, it's reported that the IRX3 gene expression level has a significant association with body weight and body composition. Conclusions: The FTO gene effects on obesity is in part due to its impact on the IRX3 gene expression level. The further studies are needed to investigate this interaction and clarify the existing mechanisms
\end{abstract}

Keywords: IRX3 gene- the FTO gene- obesity

Asian Pac J Cancer Biol, 1 (2), 33-35

\section{Introduction}

It's believed that obesity is a genetic disease and recent studies showed that $60 \%$ to $80 \%$ of obesity originates from hereditary factors [1]. The hereditary differences in secretion of effective hormones on obesity including leptin [2] and Proopiomelanocortin [3] may create suitable opportunities for the outbreak of obesity. Moreover, some genetic syndromes including Turner Syndrome and Prader-Willi syndrome are recognized as risk factors causing obesity [4]. The number and size of the adipocyte, distributing adipose tissues in the body and the rate of basic metabolism is determined by the genes [5]. Related studies with Genome (GWAS) and phenotype of obesity have successfully recognized 835 genes and 317 gene polymorphism related to obesity [6]. The role of some polymorphisms in the FTO [7], PRAR [8]adrenergic beta receiver [9] and perilipin [10] genes in the outbreak of obesity is reported. Among these genes, the FTO gene is regarded as the most important gene that influences obesity in different societies [11].
Submission Date: 03/14/2016 Acceptance Date: 05/25/2016

\section{The FTO Gene and Obesity}

The fat mass and obesity-associated (FTO) gene was recognized for the first time in the animal model as the effective gene on programmed cellular death. The rats having mutation in this gene showed fused toes and larger thymus in comparison to other rats [12-14]. The FTO gene is located on chromosome 16 and plays a role as alpha-ketoglutarate-dependent dioxygenase in DNA demethylation [15]. Duplication of FTO leads to mental retardation, obesity and some other abnormalities [16]. The FTO gene is expressed in all human body tissues, although the highest level of this gene expression is reported in the hypothalamus [17]. The relationship between FTO and obesity during childhood and adulthood is confirmed through SNPs such as rs178117449, rs9939609, rs3751812, rs1421085, rs9930506, rs7202116. Still, there is no agreement on the mechanisms of the effects of FTO on body weight and body mass index (BMI). Studies showed that polymorphisms of FTO play key roles in adjusting food and energy consumption. People with AA and AT genotype of rs9939609 polymorphism

\footnotetext{
Corresponding Author:

Dr. Maryam Gholamalizadeh

Student's Research Committee, Cancer Research Center, Shahid Beheshti University of Medical Sciences, Tehran, Iran.

Email: Gholamalizadeh@sbmu.ac.ir
} 
received 293 calories more than people with TT genotype [18]. In other studies, there was a positive relationship between the levels of FTO mRNA in adipose tissue and BMI [19-20]. Moreover, people with risk allele of FTO have less level of lipolysis in adipocytes that means the probable role of FTO in the metabolism of fats in the body [21]. The other study reported that suppression of the FTO gene in rats resulted in the reduction of body weight and the rate of white adipose tissue (WAT) to brown adipose tissue (BAT). So the reduction of the FTO gene expression may play a role in turning WAT to BAT [22]. The recent studies have been shown that it's possible that the effects of diet on body weight and body composition are appeared by the complex relationships between the FTO gene and dietary intake [23-24].

\section{The IRX3 Gene and its role in Obesity}

The IRX3 gene is a member of the Iroquois homeobox gene family appear to play multiple roles during pattern formation of vertebrate embryos [25-26]. In a recent study, it showed that the effects of the FTO gene are applied through its influence on the IRX3 gene [27]. It is reported that the IRX3 gene is controlled by the sequence of intron 1 in the FTO gene [27]. The effect of the IRX3 gene on body weight is shown in this study in which rats with knock-out IRX3 gene had lower body weight up to $25 \%$ to $30 \%$. When rats were fed with the high-fat diet, the rats with knock-out IRX3 gene did not experience any change in their weight; while the weight of control group rats increased up to $63 \%$. Moreover, in knock-out rats, the level of adipose tissue and size of adipocytes was reduced. The FTO gene expression did not change in knock-out IRX3 rats; thus, the thin phenotype of knock-out IRX3 rats did not have any relationship with the FTO expression. Indirect calorimetry in knock-out rats showed that the level of energy consumption in these rats is higher than other rats. Moreover, these results recommend that browning the WAT and activation of brown adipose tissue may lead to increasing energy consumption in knock-out rats. Browning the adipose tissue is due to increased sympathetic tone that is controlled by the hypothalamus. Results of this study showed that SNP related to obesity in the FTO gene is linked with the IRX3 gene expression and also the IRX3 expression in the hypothalamus is related with energy consumption and body composition [27].

Ragvin et al. showed that non-coding regions of the FTO and CDKAL1 genes affect obesity through effects on HHEX, SOX4, and the IRX3 genes transcription factors. HHEX and SOX4 play a role in insulin secretion from the pancreas. On the other hand, the IRX3 gene suppression in pancreas leads to increasing in epsilon cells (ghrelin producers) and reduced alpha and beta cells (insulin and glucagon secretory cells). Therefore, pancreatic IRX3 gene expression has a direct role in obesity and diabetes 2 risks [28].

Ronkainen et al. evaluated the relationship between the FTO and IRX3 genes in mice. The IRX3 gene expression levels were compared in normal mice with those in mice with suppressed FTO gene for after 4 weeks of receiving standard or high-fat diet. The results of this study indicated that the IRX3 gene expression level in mice which suppressed FTO got increased after the high-fat diet, and it is demonstrated a complex correlation between FTO, IRX3, and fat metabolism [29].

The overall conclusion obtained from a review of studies on the relationship between the IRX3 gene expression and obesity have shown that there is a correlation between the FTO and IRX3 genes and obesity as the outcome. Furthermore, the FTO gene effects on obesity might be due to its impact on the IRX3 gene expression level. The studies performed on the relationship between the IRX3 gene expression and the FTO gene were limited. Moreover, most of them focused mainly on animals. The further human studies are needed to investigate this interaction and possible mechanisms of the effects of these genes on obesity.

\section{Author Disclosure Statement}

The authors declare that they have no competing interests as defined by the Asian Pacific Journal of Cancer Prevention.

\section{References}

1. Wardle J, Carnell S, Haworth CM, Plomin R. Evidence for a strong genetic influence on childhood adiposity despite the force of the obesogenic environment. The American journal of clinical nutrition. 2008;87(2):398-404.

2. Farooqi IS, Wangensteen T, Collins S, Kimber W, Matarese $\mathrm{G}, \mathrm{Keogh}$ JM, et al. Clinical and molecular genetic spectrum of congenital deficiency of the leptin receptor. The New England journal of medicine. 2007;356(3):237-47.

3. Lee YS CB, Thompson DA, et al. A POMC variant implicates betamelanocyte-stimulating hormone in the control of human energy balance. Cell Metab 2006;;3((2):):135-40.

4. Cummings DE, Clement K, Purnell JQ, Vaisse C, Foster KE, Frayo RS, et al. Elevated plasma ghrelin levels in Prader Willi syndrome. Nature medicine. 2002;8(7):643-4.

5. O'Rahilly S, Farooqi IS. Human obesity as a heritable disorder of the central control of energy balance. International journal of obesity (2005). 2008;32 Suppl 7:S55-61.

6. Hirschhorn JN, Daly MJ. Genome-wide association studies for common diseases and complex traits. Nature reviews Genetics. 2005;6(2):95-108.

7. Wardle J, Carnell S, Haworth CM, Farooqi IS, O'Rahilly S, Plomin R. Obesity associated genetic variation in FTO is associated with diminished satiety. The Journal of clinical endocrinology and metabolism. 2008;93(9):3640-3.

8. Luan J, Browne PO, Harding AH, Halsall DJ, O'Rahilly S, Chatterjee VK, et al. Evidence for gene-nutrient interaction at the PPARgamma locus. Diabetes. 2001;50(3):686-9.

9. Jalba MS, Rhoads GG, Demissie K. Association of codon 16 and codon 27 beta 2 -adrenergic receptor gene polymorphisms with obesity: a meta-analysis. Obesity (Silver Spring, Md). 2008;16(9):2096-106.

10. Corella D, Qi L, Sorli JV, Godoy D, Portoles O, Coltell O, et al. Obese subjects carrying the $11482 \mathrm{G}>$ A polymorphism at the perilipin locus are resistant to weight loss after dietary energy restriction. The Journal of clinical endocrinology and metabolism. 2005;90(9):5121-6.

11. Scuteri A, Sanna S, Chen WM, Uda M, Albai G, Strait J, et al. Genome-wide association scan shows genetic variants in the FTO gene are associated with obesity-related traits. PLoS genetics. 2007;3(7):e115. 
12. Peters T, Ausmeier K, Ruther U. Cloning of Fatso (Fto), a novel gene deleted by the Fused toes $(\mathrm{Ft})$ mouse mutation. Mammalian genome : official journal of the International Mammalian Genome Society. 1999;10(10):983-6.

13. Kim B, Kim Y, Cooke PS, Ruther U, Jorgensen JS. The fused toes locus is essential for somatic-germ cell interactions that foster germ cell maturation in developing gonads in mice. Biology of reproduction. 2011;84(5):1024-32.

14. Jia G, Fu Y, Zhao X, Dai Q, Zheng G, Yang Y, et al. N6-methyladenosine in nuclear RNA is a major substrate of the obesity-associated FTO. Nature chemical biology. 2011;7(12):885-7.

15. Gerken T, Girard CA, Tung YC, Webby CJ, Saudek V, Hewitson KS, et al. The obesity-associated FTO gene encodes a 2-oxoglutarate-dependent nucleic acid demethylase. Science (New York, NY). 2007;318(5855):1469-72.

16. Freathy RM, Timpson NJ, Lawlor DA, Pouta A, Ben-Shlomo $\mathrm{Y}$, Ruokonen A, et al. Common variation in the FTO gene alters diabetes-related metabolic traits to the extent expected given its effect on BMI. Diabetes. 2008;57(5):1419-26.

17. Frayling TM, Timpson NJ, Weedon MN, Zeggini E, Freathy RM, Lindgren CM, et al. A common variant in the FTO gene is associated with body mass index and predisposes to childhood and adult obesity. Science (New York, NY). 2007;316(5826):889-94.

18. Speakman JR, Rance KA, Johnstone AM. Polymorphisms of the FTO gene are associated with variation in energy intake, but not energy expenditure. Obesity (Silver Spring, Md). 2008;16(8):1961-5.

19. Dina C, Meyre D, Gallina S, Durand E, Korner A, Jacobson $\mathrm{P}$, et al. Variation in FTO contributes to childhood obesity and severe adult obesity. Nature genetics. 2007;39(6):724-6.

20. Timpson NJ, Emmett PM, Frayling TM, Rogers I, Hattersley AT, McCarthy MI, et al. The fat mass- and obesity-associated locus and dietary intake in children. The American journal of clinical nutrition. 2008;88(4):971-8.

21. Do R BS, Desbiens K, Belisle A, Montpetit A, Bouchard C, et al. Genetic variants of FTO influence adiposity, insulin sensitivity, leptin levels, and resting metabolic rate in the Quebec Family Study. . Diabetes. 2008;; 57((4):):1147-50.

22. Claussnitzer M, Dankel SN, Kim KH, Quon G, Meuleman W, Haugen C, et al. FTO Obesity Variant Circuitry and Adipocyte Browning in Humans. The New England journal of medicine. 2015;373(10):895-907.

23. Kalantari N DS, Mohammadi NK, Gholamalizadeh M, Pazan N. Review of studies on the fat mass and obesity-associated (FTO) gene interactions with environmental factors affecting on obesity and its impact on lifestyle interventions. ARYA Atheroscler, North America, 12, feb. 2017.

24. Doaei S KN, Mohammadi NK, Tabesh GA, Gholamalizadeh M. . Macronutrients and the FTO gene expression in hypothalamus; a systematic review of experimental studies, Indian Heart J http://dx.doi.org/10.1016/j. ihj.2017.01.014(2017), [

25. Bellefroid EJ, Kobbe A, Gruss P, Pieler T, Gurdon JB, Papalopulu N. Xiro3 encodes a Xenopus homolog of the Drosophila Iroquois genes and functions in neural specification. The EMBO journal. 1998;17(1):191-203.

26. Lewis MT, Ross S, Strickland PA, Snyder CJ, Daniel CW. Regulated expression patterns of IRX-2, an Iroquois-class homeobox gene, in the human breast. Cell and tissue research. 1999;296(3):549-54.

27. Smemo S, Tena JJ, Kim KH, Gamazon ER, Sakabe NJ, Gomez-Marin C, et al. Obesity-associated variants within FTO form long-range functional connections with IRX3. Nature. 2014;507(7492):371-5.
28. Ragvin A, Moro E, Fredman D, Navratilova P, Drivenes $\mathrm{O}$, Engstrom PG, et al. Long-range gene regulation links genomic type 2 diabetes and obesity risk regions to HHEX, SOX4, and IRX3. Proceedings of the National Academy of Sciences of the United States of America. 2010;107(2):77580.

29. Ronkainen J, Huusko TJ, Soininen R, Mondini E, Cinti F, Makela KA, et al. Fat mass- and obesity-associated gene Fto affects the dietary response in mouse white adipose tissue. Scientific reports. 2015;5:9233.

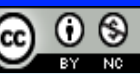

This work is licensed under a Creative Commons AttributionNon Commercial 4.0 International License. 